\title{
Article \\ Consumers' Attitude and Intention towards Organic Fruits and Vegetables: Empirical Study on Romanian Consumers
}

\author{
Violeta Radulescu ${ }^{1, *(D)}$, Iuliana Cetina ${ }^{1}$, Anca Francisca Cruceru ${ }^{1}$ and Dumitru Goldbach ${ }^{2}$ \\ 1 Department of Marketing, The Bucharest University of Economic Studies, 010374 Bucharest, Romania; \\ iuliana.cetina@mk.ase.ro (I.C.); anca.cruceru@mk.ase.ro (A.F.C.) \\ 2 Department of Science and Engineering, Faculty of Science and Engineering, Valahia University, \\ 130086 Târgoviște, Romania; goldbach.dumitru@gmail.com \\ * Correspondence: violeta.radulescu@mk.ase.ro
}

Citation: Radulescu, V.; Cetina, I.; Cruceru, A.F.; Goldbach, D. Consumers' Attitude and Intention towards Organic Fruits and Vegetables: Empirical Study on Romanian Consumers. Sustainability 2021, 13, 9440. https://doi.org/ $10.3390 /$ su13169440

Academic Editor: Djin Gie Liem

Received: 15 July 2021

Accepted: 20 August 2021

Published: 23 August 2021

Publisher's Note: MDPI stays neutral with regard to jurisdictional claims in published maps and institutional affiliations.

Copyright: (c) 2021 by the authors. Licensee MDPI, Basel, Switzerland. This article is an open access article distributed under the terms and conditions of the Creative Commons Attribution (CC BY) license (https:// creativecommons.org/licenses/by/ $4.0 /)$.

\begin{abstract}
Organic farming is one of the fastest growing sectors, both in developed and developing countries. Although Romania is in sixth place at the level of the European Union in terms of agricultural area, the share of ecologically certified areas is low. The fruits and vegetables sector is the most important for the agri-food production in Romania, accounting for $58 \%$ of the total cultivated area. In recent years, there is a tendency for consumers to focus on healthy diets with safe, high quality foods and high nutritional compounds from unpolluted areas. However, the Romanian market of organic fruits and vegetables is still underdeveloped due to the small number of consumers of organic products. The future of organic farming is largely dependent on attitude and consumer demand. The purpose of this paper is to study the attitudes and intentions of Romanian consumers towards the consumption of organic fruits and vegetables through direct research among 268 individuals. The results show that the attitudes of individuals towards the consumption of organic fruits and vegetables is directly and positively influenced by the information that individuals have about the characteristics of organic products, their personal needs and motivations, but also by external influences, and the purchase barriers do not represent elements with a strong enough influence on the attitude and intention.
\end{abstract}

Keywords: organic fruits and vegetables; attitude; intention to buy; need and motivation; purchase barriers

\section{Introduction}

The last decades are characterized by a permanent concern for the protection of the environment and human health. In this context of sustainable development, agriculture also faces new challenges: to produce more, to pollute less, and to distribute better [1]. It has thus developed, at a rapid pace, organic farming, which encompasses new environmental, social, economic, and ethical dimensions [2]. The application of the new EU legislation on increasing the production of organic food in Europe since 2009 has resulted in a growing awareness of the benefits of organic food on health and the environment, with a direct impact on market growth [3]

Currently, the organic sector is one of the fastest growing sectors of the food industry in many European countries. In Europe, the market for organic products has grown a lot in the last 10 years, however it is still very small compared to the conventional products market $[4,5]$.

The organic fruits and vegetables sector also registered considerable growth, both as a cultivated area and as a consumer demand [6]. A change in dietary preferences, sociodemographic factors, raising awareness about the health benefits of fruits and vegetables, and marketing policies of the food industry have led to an increase in the market for organic fruits and vegetables in Europe [2]. 
This increase in demand will continue in the coming years, even if the situation differs from one country to another in terms of type and quantities of production [7].

In practice, the analysis of consumer demand and behavior is required to be done in the geographical and economic-social context of a country. The need to treat agri-food consumption differentially according to the level of development of the countries is evident as the differences between the food consumption models in developed and developing countries are very high [8].

Romania is in the sixth place among the EU 27 in agricultural surface/per inhabitant, with $0.411 \mathrm{ha} /$ person, and the organically certified areas increase significantly from year to year [2]. The fruits and vegetables sector is the most important for the agri-food production in Romania, considering that $58 \%$ of the total arable area cultivated at the national level is cultivated with vegetables, to which $3 \%$ fruit production is added [2]. The increased demand for organically grown products, consumers' fears for chemical residues from fresh products, and increasing awareness about ecological procedures are some of the main reasons for the growth of organic farming in Romania [9].

However, the share of certified areas of organic farming in the total agricultural areas is very low compared to other European countries: $2 \%$ in Romania compared to $23.4 \%$ in Austria, $14.5 \%$ in Italy, 9.6\% in Slovenia, 6.6\% in France, and 4,3\% in Hungary [10].

The rapid growth in demand and production of these food categories necessitate continuous research in order to document and understand the evolution of the markets. Due to the lack of consumer research in Romania and the continuously changing trends among Romanian consumers, this study can help market actors and policy makers to follow the updated buying behaviors and attitudes of consumers. In this paper, we are trying to contribute to a better acquaintance with consumers' attitudes and perception towards organic and integrated fruit and vegetables in the case of Romania through a direct research among Romanian consumers. Studying the literature, we proposed a conceptual model, which aims to determine, among other things, the influence of individuals' attitudes on the intention to purchase organic vegetables and fruits. Results of this research are aimed at enabling more effective marketing strategies of organic and integrated fruit and vegetable producers in Romania, but also to support public policy initiatives to stimulate demand of these categories of food.

\section{Literature Review}

In order to understand the consumer behavior of organic products, to clearly identify the research objectives and to establish the conceptual model of the research, we conducted a research of secondary sources by literature review.

\subsection{Consumer Attitude and Behavior of Organic Fruits and Vegetables}

Consumer behavior is a dynamic process as a result of the continuous changes of the consumer's ideas, perceptions and activities [11]. The purchasing and consumption behavior of food consumers has undergone a considerable change in last few years [8], being the subject of numerous studies, both in a broad sense and with a special focus on organic fruits and vegetables $[12,13]$.

The studies show different results depending on the country or the year in which they were performed. While in developed countries, the consumer is more familiar with the consumption of organic products and accepts them as part of their lifestyle [8], in the developing ones, the consumer is at the beginning of this process [14].

Attitudes and consumer behaviors towards organic products are influenced by a number of endogenous factors such as needs and motives, learning, personality, selfconcept and attitude [15] and exogenous factors such as culture, reference group, family, and socioeconomic situations. Studies have shown that the purchasing behavior of food consumers is influenced by a combination of social, economic, cultural, and psychological factors $[16,17]$. 


\subsubsection{Personal and Sociodemographic Factors}

Sociodemographic factors such as age, gender, number and structure of family members, employment status, education, economic situation, etc., influence the attitude and behavior of the consumer of food products $[18,19]$. Studies have shown that families with children are more concerned with healthy eating than single people who prefer junk food. In this respect the concern for children healthy diet has also been identified [20,21].

Gender plays a large role in purchasing decisions [19], with women generally focusing more on fruit and vegetables because they feel more responsible for the health of the family than men. In addition, according to another study, women appreciate that organic products have a better taste and quality [14].

Regarding age, some studies have shown that people who buy organic products are generally young, up to 45 years old [22]. It has been observed that the level of education significantly affects the purchasing behavior of food consumers [23] and the type of channel [22]. Regular consumers of organic foods are, in most countries, those with a high level of education, who also have more knowledge about organic products [14,18].

Yiridoe et al. [13] showed the importance of knowledge about organic food as a factor that strongly affects the purchase decision, because consumers without information can not differentiate organic products from conventional products [24]. A high level of knowledge determines a high confidence in the certification and labeling system according to the regulations [25]. Maniatis [26] states that even though consumers are more informed about the concept of organic products, organic consumers are sophisticated buyers, and marketers need to pay extra attention to defining the product specifications. The income also influences the consumer behavior of organic fruits and vegetables. Some research has shown that consumers with higher incomes are more inclined to buy organic products than those with low incomes [14].

\subsubsection{Consumer Attitude and Motivation}

Attitude is one of the strongest precursors of buying intentions [27] and can strongly affect actual consumption or buying behavior towards organic foods [13].

Regarding organic fruits and vegetables, consumers have a positive attitude because they perceive them as being of higher quality, safer, and fresher [28]. The positive attitude of consumers can be attributed to their beliefs that, compared to conventionally produced foods, organic foods have a visibly greater capacity to promote sustainability and protect the environment [29].

According to some surveys, consumers with positive attitudes towards organic products were more willing to pay more for organic food than consumers with less positive attitudes [30,31].

The purchase motivation has also been the subject of numerous studies. Thus, most studies have indicated that the main reason for buying organic fruits and vegetables is health, because organic products have less pesticides, additives, fertilizers and more vitamins and minerals [32]. Other studies have shown that concern for the environment and resources is, after health, the second reason for buying vegetables and organic fruits $[14,18]$, especially among young people.

Other researchers also highlighted the same reasons for buying organic fruits and vegetables, such as the health of the products compared to conventional food options [28,33], as well as their freshness, and taste, organic products taste more natural, intense and rich flavour. Organic products are perceived as being of a higher quality, being premium products, as such and their price is higher than that of conventional products [34].

Other reasons identified by studies conducted in different countries are the origin of the products. Consumers prefer to buy from their local area or country to support local small farmers and to stand against big international food producers [18]. Trust and safety are also important as the consumer wants to be sure that the product really comes from organic farming, without any tricks in the certification and production side [35]. 


\subsubsection{Barriers to Buying Organic Fruits and Vegetables}

The purchase barriers have also been the subject of numerous studies. The importance of price as a barrier to the purchase of organic products from unconventional production systems is confirmed by an increasing number of studies [36] assessing consumers' willingness to pay more for environmentally friendly or safe products $[37,38]$ and this will generate less repeat purchase as well [39]. Especially in Eastern European countries, the price of these products is considered high in relation to the purchasing power of consumers; only those with high incomes can buy them [14]. Moreover, according to Feldmann and Hamm (2015) [40], the willingness to pay more is rather declarative and overestimated, as it has been observed that during the acquisition it does not happen to pay more.

Another impediment in the purchase of these products is their availability. There is a limited amount of organic fruits and vegetables on the market, and most consumers are shopping near home or at work because they are tired and do not have the time and desire to look for organic products [32]. Consumers may consider the health benefits of organic vegetables, but pragmatic buyers buy based on the availability, visibility of products and the price of each product [41].

Other studies have highlighted the importance of the appearance of the products. If the appearance is not satisfactory to consumers, they feel cheated, and perceive the products as being of poor quality [18].

Some studies have highlighted other barriers, such as the origin of the products, many being imported products, lack of taste, or lack of information [42,43]. Many consumers do not have enough information to differentiate between natural, organic, fair trade, or regional products [44], especially in developing countries, where the main source of information is media.

\subsection{Organic Market of Fruits and Vegetables in Romania}

Organic farming is one of the fastest growing market segments in both developed and developing countries [45]. Agricultural policies in many developed countries, including the European Union, support organic farming and other sustainable agricultural practices [46] as a result of the benefits it brings to human health and the environment. Fruits and vegetables are the largest segment of the European organic food market, with almost half of total organic food sales [17] and about 2 percent of all fruit and vegetable sales in West Europe [47].

The fruit and vegetable sector is marked by the internationalization of productions, both at EU level and at the global level [2]. In the market of 500 million consumers as the EU constitutes, interregional competitors are struggling to satisfy an increasingly demanding and difficult consumer loyalty [10]. Consumption patterns vary widely from region to region and within the same regions. During the last three decades, the network of large commercial areas (hypermarkets, super stores, discounts, etc.) has had an increasingly strong influence in the context of the evolution of the traditional structure of the distribution channel [48].

In developing countries, the growth of sales of fresh fruit and vegetables in supermarkets tends to lag behind the increase in sales of processed food, as most households continue to buy fruits and vegetables from traditional retailers (specialized stores and agri-food markets), even if they buy many other products in supermarkets [49].

As far as production, the high costs, especially with the labor force, the insufficient knowledge, and the difficulty of moving from conventional to organic farming are limiting factors for the development of organic farming [50]. In addition, organic products are seasonal, perishable [8], and their availability, assortment, and price can vary widely between seasons [51].

In practice, the analysis of consumer demand and behavior is required to be done in the geographical and economic-social context of a country [2]. The need to treat agri-food consumption differentially according to the level of development of the countries is evident 
as the differences between the food consumption models in developed and developing countries are very high [52].

As for Romania, agriculture still holds a significant share of the GDP, even if, as a result of the transformation of the Romanian economy, the share has decreased from year to year in the last three decades. With an agricultural area of 12.5 million hectares, Romania ranks fifth at the EU level, after France (27.8 million hectares), Spain (23.2 million hectares), Germany (15.2 million hectares), and Poland (14.4 million hectares). Cumulatively, these six countries own more than half of the total agricultural area used in the European Union, which reaches about 171.3 million hectares. The Report Organic Farming in EU from the European Commission (2019) [9] shows that Romania is the country with the most farms in the EU (3422) representing one third (33\%) of the total existing ones. Most farms in Romania, however, are small, being in the subsistence category: $92 \%$ of the total farms have less than five hectares, as opposed to the Union average, where $65 \%$ of the total farms are small. According to Eurostat (2019), in Romania, large farms, run by entrepreneurs and 50 hectares and over, represent $0.5 \%$ of total farms [53].

The last few years have brought investments in agriculture and an optimization of production. This increase, however, did not lead Romania to leading places in the share of organic products from the total agricultural area at national level (only $2 \%$ in Romania), and Romania is much lower compared to other countries (Estonia 20.5\%, Czech Republic $12.2 \%$, Slovakia $10 \%$, Lithuania $8.1 \%$, Germany $8.2 \%$, Hungary $4.3 \%$, Poland $3.4 \%$, Bulgaria $2.9 \%)[54]$.

Romanian agriculture is still affected by the fragmentation of agricultural lands, the technological gap, the lack of irrigation systems, and the lack of professional training of the labor force in agriculture [55]. Another disadvantage of the ecological sector in Romania is related to the underdeveloped nature of the internal market, respectively to the small number of consumers of organic products. Moreover, in Romania there is a lack in the permanent collection of statistical data regarding the sale and purchase of organic products on the domestic market [10].

\section{Materials and Methods}

To study the attitude and intention to buy of the Romanian consumer towards organic fruits and vegetables, we conducted a direct research through an online survey, based on a structured questionnaire, developed according to the purpose and the objectives of research. According to the purpose of the research, the objectives of the research aim at evaluating the points of view of the Romanian consumers regarding the following aspects:

1. consumer understanding of the characteristics of organic fruits and vegetables;

2. personal needs and motivations for buying organic fruits and vegetables;

3. external factors that influence the purchase decision;

4. purchase barriers;

5. the attitude of Romanian consumers towards organic fruits and vegetables;

6. the intention to buy organic fruits and vegetables.

Based on the studied literature $[16,17,27]$, we proposed a conceptual model (Figure 1) in order to study the effect between variables. The model aims to determine, among other things, the influence of individuals' attitudes on the intention to purchase organic vegetables and fruits. The research model was conceptualized with independent variables (consumer understanding of the characteristics of organic fruits and vegetables, external influences, and purchase barriers). The dependent variables are personal needs and motivation, attitude, and intention to buy. The research objectives were associated with 8 hypotheses regarding the relationships between the variables involved in the model, namely:

- H1: Variable Consumer understanding of the characteristics of organic fruits and vegetables has a direct and positive effect on the variable Personal needs and motivations.

- H2: Variable Consumer understanding of the characteristics of organic fruits and vegetables has a direct and positive effect on the variable Attitude towards organic fruits and vegetables. 
- H3: The variable Personal needs and motivations has a direct and positive effect on the variable Attitude towards organic fruits and vegetables.

- H4: The variable External influences has a direct and positive effect on the variable Attitude towards organic fruits and vegetables.

- H5: The variable Purchase barriers has a direct and positive effect on the variable Attitude towards organic fruits and vegetables.

- H6: Variable The attitude towards organic fruits and vegetables has a direct and positive effect on the variable Intention to buy fruits and vegetables.

- H7: The variable External influences has a direct and positive effect on the variable Intention to buy organic fruits and vegetables.

- H8: The variable Purchase barriers has a direct and positive effect on the variable Intention to buy organic fruits and vegetables.

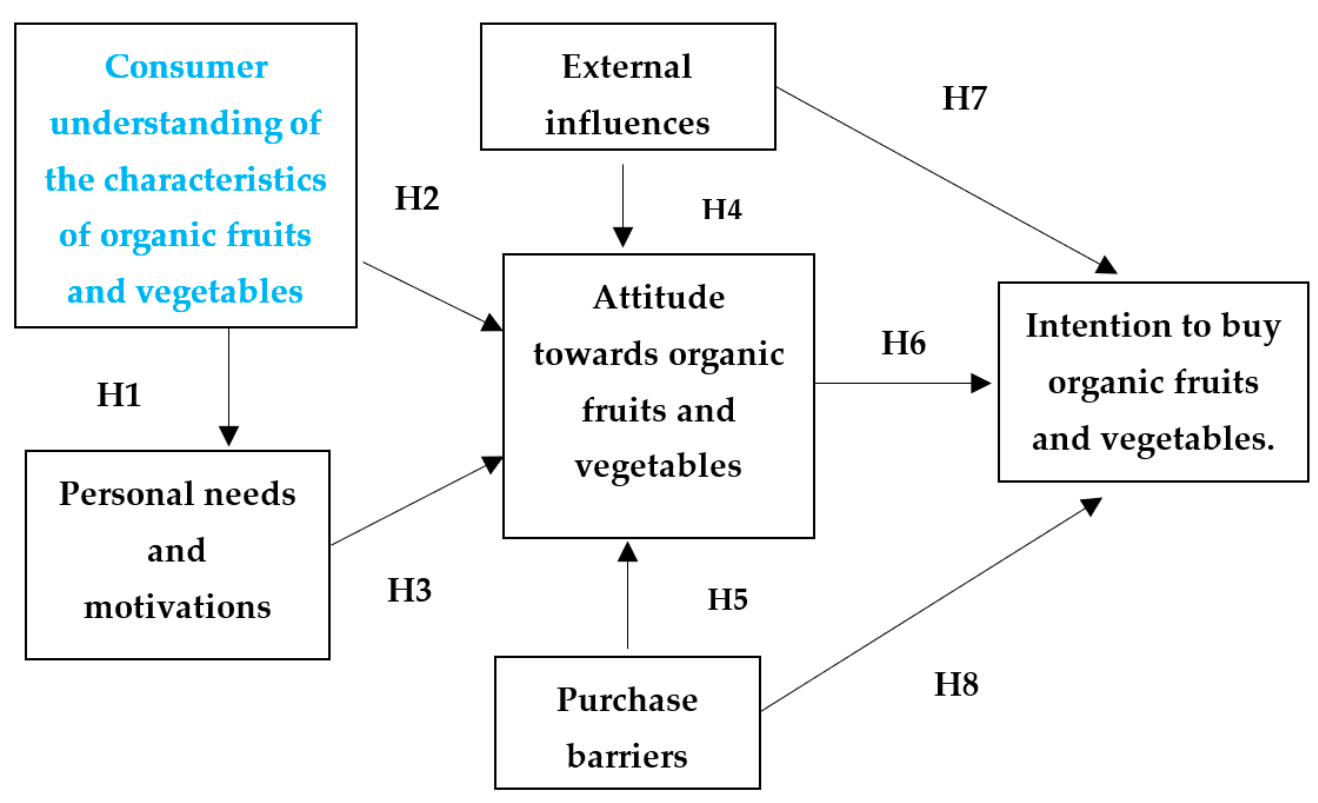

Figure 1. The proposed conceptual model.

All latent variables included in the model were measured by at least 5 items, using 5-step semantic differentials (from 1-to a very small extent, to 5-to a very large extent). Variables of Consumer understanding of the characteristics of organic fruits and vegetables, Personal needs and motivations, External influences, and Purchase barriers were considered to be latent formative variables, and Attitude towards organic fruits and vegetables and Intention to buy organic products were considered to be latent reflective variables. A reflective latent variable is one in which all the indicators are expected to be highly correlated with the latent variable score, while a formative latent variable is one in which the indicators are expected to measure certain attributes of the latent variable, but the indicators are not expected to be highly correlated with the latent variable score [56].

The study was conducted in March 2021 on a sample of 268 respondents through an online survey method as a tool based on a structured questionnaire, developed according to the purpose and the objectives of research. For sampling, the convenience sampling method was used. The invitation to complete the questionnaire was sent to contacts from the LinkedIn ${ }^{\mathrm{TM}}$ and Facebook ${ }^{\mathrm{TM}}$ online social networks. Although it is an exploratory online research, following the analysis and interpretation of information collected from respondents, the results are valuable if they are corroborated by other studies conducted on the same subject.

The sample structure is shown in Table 1: 
Table 1. The sample structure.

\begin{tabular}{ccc}
\hline Characteristics & Share in the Sample & Percentage \\
\hline \multirow{2}{*}{ Sex } & Female & $71.64 \%$ \\
& Male & $28.36 \%$ \\
Age & $18-25$ years old & $29.85 \%$ \\
& $26-35$ years old & $20.89 \%$ \\
& $36-45$ years old & $36.94 \%$ \\
& $46-60$ years old & $8.95 \%$ \\
Level of studies & Over 60 years old & $3.35 \%$ \\
& ISCDE * 4 or less & $20.14 \%$ \\
& ISCDE 5 or 6 & $52.61 \%$ \\
Household members & ISCDE 7 or more & $27.23 \%$ \\
& 1 member & $2.23 \%$ \\
& 2 members & $22.01 \%$ \\
Number of children & 3 members & $28.73 \%$ \\
& 4 members or more & $47.01 \%$ \\
& No children & $48.89 \%$ \\
& 1 or more children & $51.11 \%$ \\
& Under EUR 500 & $20.14 \%$ \\
Monthly net income & EUR 501-800 & $33.20 \%$ \\
& EUR 801-1100 & $16.04 \%$ \\
& EUR 1101-1400 & $14.55 \%$ \\
& Over EUR 1400 & $7.08 \%$ \\
& No income & $8.95 \%$ \\
Residence & Urban & $79.1 \%$ \\
& Rural & $20.9 \%$ \\
\hline
\end{tabular}

* ISCED = International Standard Classification of Education. ISCED 4 or less is roughly equivalent up to postsecondary, non-tertiary education. ISCED 5 and 6 is equivalent to short-cycle tertiary education and bachelor or equivalent, respectively. ISCED 7 or more represent master's or doctoral education.

\section{Results}

The measurement of the consumer understanding of the characteristics of organic fruits and vegetables by consumers was done by researching how respondents define organic products, because although organic agriculture is defined in Romania as focusing on obtaining fresh and authentic agri-food products that meet the natural and environmental factors [57], for the consumer, these products are associated with products purchased from the market or directly from the source. In the view of the Romanian consumer, ecological is declined for natural or traditional [58]. Organic products are developed in full conformity with the conditions and regulations for the organic farming sector established by the European Union. There are some key principles, such as: "prohibition of the use of GMOs; forbidding the use of ionising radiation; limiting the use of artificial fertilisers, herbicides and pesticides; prohibiting the use of hormones and restrict the use of antibiotics and only when necessary for animal health" that govern all areas of organic production [59]. In addition to all these formal characteristics, consumers tend to associate organic products with certain characteristics, and through this research, we sought to find out what those characteristics are.

The research results indicated that respondents understand organic products to mean more nutritious and healthier products (average score being 4.78); natural products, without chemical additives, genetically modified organisms, and growth stimulants (average score being 4.77); environmentally friendly, non-polluting, and sustainable agricultural processes (average score being 4.45); and also high quality products certified by an authorized body (average score being 4.36).

The sources that respondents use to find out about the organic vegetables and fruits are personal experience $(67.53 \%)$, product packaging and labels $(54.47 \%)$, opinions of relatives/friends/acquaintances (33.20\%), Internet/media (27.23\%), information and offers in stores $(23.13 \%)$, information provided by sellers $(14.17 \%)$, and other sources $(7.08 \%)$. 
The assessment of respondents' needs and motivations to consume organic products highlighted the fact that the option to purchase organic vegetables and fruits is mainly due to the fact that individuals want to consume tastier products (average score 4.47), but also to the fact that individuals have decided to have a healthier/balanced lifestyle (average score 4.36). The positive past experience associated with consuming these products (average score 4.35 ) is another reason to consume organic fruits and vegetables. In addition, the awareness of the health benefits of natural products that are free of chemical additives (4.30), the desire to protect nature and the environment (4.23), and the desire to support organic farming (4.19) are other important elements that determine respondents to choose these products. Regarding the source of organic vegetables and fruits, taking into account a number of specific criteria, most respondents choose local products (over 60\%), and when they are not available, they choose imported ones.

Regarding external influences, the research results indicated that the option of individuals to consume organic vegetables and fruits was encouraged by their social status (3.18), family members (3.80), friends/acquaintances (3.41), the fact that other Romanian consumers choose these products (3.08), the fact that more and more agricultural producers (3.23) and an increasing number of traders (3.10) offer these products for sale, and the fact that more and more advertising messages promote this type of product (3.11).

Respondents' attitudes towards organic fruits and vegetables were studied in comparison with ordinary fruits and vegetables, the research results indicated that respondents consider organic vegetables and fruits as more natural alternatives that are produced without chemical additives, genetically modified organisms, and growth stimulants (4.46); are more nutritious and beneficial to health (4.43); more environmentally friendly, the products being from clean and sustainable agriculture (4.27); are of a higher quality, being certified by an authorized body (4.22); and are also an alternative with a good value for the money (4.05).

The analysis of the respondents' opinions regarding the barriers to buying organic fruits and vegetables revealed that the higher price compared to ordinary products can be considered the biggest obstacle, with an average score of 3.77. This is followed by the lower availability of stocks in shops/stores (3.73), the lack of detailed information on the producer (3.72), the lack of confidence in the origin of the products or their cultivation (3.68), the seasonality of certain product categories (3.65), and the higher perishability or shorter shelf life (3.50). However, when asked how much they would be willing to pay more for organic vegetables and fruits than usual, most respondents said they would pay $10-20 \%$ more $(54.47 \%)$, followed by those who would pay less than $10 \%$ more $(17.16 \%)$, those who would pay $21-30 \%$ more $(14.92 \%)$, and those who would pay more than $30 \%$ more $(6.71 \%)$. Only $6.71 \%$ of respondents said they were not willing to pay anything extra to buy organic vegetables and fruits.

Following the analysis of data on the intention to buy organic fruits and vegetables, it turned out that the respondents intend to continue to buy organic vegetables and fruits as often or more often than at present (average score 4.29). They will also continue to buy organic fruits and vegetables even if their price is higher than that of regular products (average score 4.08). Respondents consider it a responsible and wise decision for them and/or their family members to continue to buy organic fruits and vegetables (average score 4.33), thus protecting the environment (average score 3.94) and supporting producers and organic farming (score average 4.03). This variable aimed to analyze the extent to which respondents intend to buy and consider it important to continue to buy organic products, taking into consideration a number of premises, such as the following: Are they willing to continue to buy organic fruits and vegetables even if their price is higher than that of regular products?; Is it a responsible and wise decision for them to continue to buy organic fruits and vegetables?; Is it important to continue to buy organic fruits and vegetables in order to protect the environment?; and Is it important to continue to buy organic fruits and vegetables to support organic producers and agriculture? 
For testing and validation of the proposed conceptual model, the specific methodology of modeling by structural equations (SEM) was used, applied through the program WarpPLS 7.0. In this sense, the stages of the SEM-specific procedure were completed, namely, the stage of testing the reliability of the measurements and the stage of testing the hypotheses. The first step, testing the reliability of the measurements, was to test the reliability of the measurements based on their internal consistency, using the Cronbach's alpha coefficient method and the composite reliability coefficient method, followed by testing the validity of the measurements. The second stage of the hypothesis testing followed the analysis of the direct connection coefficients, based on which the research hypotheses can be validated or invalidated. Based on the analysis of the Cronbach's alpha coefficient and the composite reliability coefficient, performed using the WarpPLS program and presented in Table 1, it is observed that in the case of all latent variables, excellent values of coefficients over 0.8 are obtained. These values indicate a very good reliability of the measurements performed in the research.

The validity of the measurements used in the research was determined based on the average extracted variance (AVE), calculated using the WarpPLS program. According to Table 2, it is observed that the principle of convergent validity is observed, all AVE values are over 0.5 , but it is lower than the composite reliability coefficients.

Table 2. Reliability and validity of latent variable measurements.

\begin{tabular}{cccc}
\hline Variable & Cronbach's Alpha & $\begin{array}{c}\text { Composite Reliability } \\
\text { Coefficient }\end{array}$ & $\begin{array}{c}\text { Average Extracted } \\
\text { Variance (AVE) }\end{array}$ \\
\hline $\begin{array}{c}\text { Consumer understanding of the } \\
\text { characteristics of organic products }\end{array}$ & 0.905 & 0.929 & 0.725 \\
Personal needs and motivations & 0.897 & 0.921 & 0.662 \\
Attitude towards organic products & 0.900 & 0.926 & 0.716 \\
External influences & 0.921 & 0.937 & 0.681 \\
Consumption barriers & 0.860 & 0.896 & 0.591 \\
Intention to buy organic products & 0.882 & 0.914 & 0.680 \\
\hline
\end{tabular}

The research hypotheses were tested by calculating the Beta coefficients (standardized) corresponding to the causal relationships in the model. The hypotheses can be validated under the conditions of values $\beta>0.1$, at a significance threshold of $p<0.05$. Therefore, according to the results in Table 3, out of the eight proposed hypotheses, only six could be validated.

Table 3. Validation of hypotheses by Beta coefficients.

\begin{tabular}{cccc}
\hline Hypothesis & $\boldsymbol{\beta}$ & $\boldsymbol{p}$ & Hypothesis Validation \\
\hline H1 & 0.52 & $<0.01$ & Yes \\
H2 & 0.23 & $<0.01$ & Yes \\
H3 & 0.44 & $<0.01$ & Yes \\
H4 & 0.13 & $=0.02$ & Yes \\
H5 & 0.01 & $=0.45$ & No \\
H6 & 0.50 & $<0.01$ & Yes \\
H7 & 0.20 & $<0.01$ & Yes \\
H8 & 0.64 & $=0.28$ & No \\
\hline
\end{tabular}

The three most important conditions that must be met to validate the model analyzed based on the SEM procedure by the variance method are that the probability values associated with the Average Path Coefficient (APC) and Average R-Squared (ARS) indicators be less than 0.05 and the Average Block VIF (AVIF) indicator value be less than 5. Thus, the calculated values of the APC $=0.259, p<0.001 ;$ ARS $=0.366, p<0.001$; and AVIF $=1.575$ show that the model can be validated (Figure 2). The coefficients of the determination $\mathrm{R}^{2}$, calculated using the program WarpPLS, indicate the explanatory power of the predictor 
variables on the three dependent variables within the model. Thus, by analyzing the values of the determination coefficients $\mathrm{R}^{2}$ it is observed that the variable Consumer understanding of the characteristics of organic products has a power to explain the variable Needs and personal motivations of $27.3 \%$. The variable of The attitude towards organic products is explained by the variables of Knowledge of the characteristics of organic products, Personal needs and motivations, and External influences by a proportion of $43.8 \%$. The varible of The intention to buy organic products is explained based on the variables of Attitude towards organic products and External influences by a proportion of $38.5 \%$.

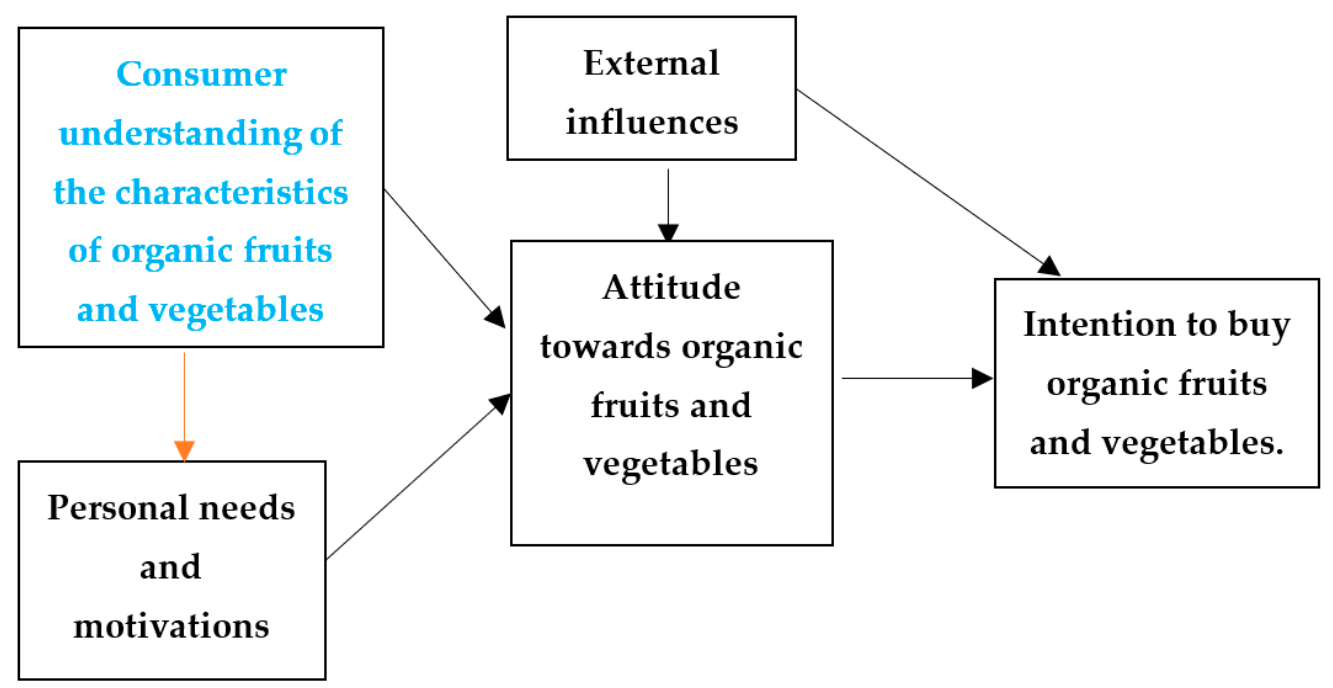

Figure 2. The validated conceptual model.

\section{Discussion}

Food consumption patterns are changing rapidly, and consumers are concerned about the health and nutritional values related to food. Therefore, organic products are gaining acceptance among consumers, who are increasingly aware of their health and of environmental protection [41].

Given that consumers in each country have a different perspective/attitude towards organic products, surveys on consumer behavior are of great importance in order to obtain information on current market trends and policies. In addition, producers, traders, and distributors of organic fruit and vegetables could use these valuable results to develop and promote products in line with consumer requirements.

The present study explored the attitude and behavior of Romanian consumers towards organic fruits and vegetables. Romanian consumers define organic fruits and vegetables primarily by the fact that they are healthier and more nutritious than conventional ones and by the fact that they come from organic, non-polluting, and sustainable agricultural processes and are certified by an authorized body. This aspect has been highlighted by other studies conducted in other countries $[5,60]$

Regarding the reasons for the purchase of organic fruits and vegetables by the Romanians, in the first places are the taste and the positive impact on health, reasons that have been identified by other studies $[28,41,61]$. This is opposed to consumers from other countries, who considered the nutritional content or the ecological impact of the product to be the main reasons for purchasing [62].

The attitude of the Romanian consumer of organic fruits and vegetables is influenced to a large extent by external factors, including the social status of the consumer and the family, which is supported by the results of research conducted among consumers in Cyprus [60], Slovenia [17], and Poland [5].

According to the data resulting from the research, the consumption barriers do not represent elements with a strong enough influence on the attitude and intention of indi- 
viduals to buy. This result is also supported by another study conducted in Romania [63], which shows that the higher price and availability are not barriers to buying organic fruits and vegetables for more than half of those interviewed, which is not found in studies in other countries $[17,36,64]$. This aspect can be justified both by the Romanian tradition of eating fruits and vegetables as natural as possible purchased from specialized stores and agri-food markets [44], but also by their desire to eat fruits and vegetables that are as tasty and healthy as possible [9].

In short, it can be said that the attitude of individuals towards organic fruits and vegetables is directly and positively influenced by the information that individuals have about the characteristics of organic products, their personal needs and motivations, but also by external influences.

\section{Conclusions}

\subsection{Managerial and Theoretical Implications}

This study can be useful to both policy makers and producers of organic vegetables and fruits on the Romanian market because there is currently insufficient research on changing trends in the attitudes and intentions of Romanian consumers to buy organic fruits and vegetables. The results of this research will be useful for the adaptation of efficient marketing strategies of organic fruits and vegetables in Romania and, at the same time, will support public policy initiatives to stimulate the demand and consumption of organic fruits and vegetables.

In the context of sustainable development, this study may be useful to decision makers in the agri-food industry, agri-food specialists, and marketers who will have to take into account consumers' sustainable food choice.

In order for this sector to reach its development potential, it needs the collaboration of all stakeholders-consumers, producers, processors, retailers, certification bodies, and ministries-in order to establish a viable and current strategy on organic farming. At present, Romania does not have such a national strategy, and the dialogue on this subject between the parties involved does not exist [65].

Increasing awareness of the health benefits of organic fruits and vegetables as well as marketing decisions in the food industry will support the production of organic agricultural products that aim for long-term healthy organic consumption.

The future of organic farming in Romania also depends on consumer demand. Thus, a consumer-oriented approach to understanding organic farming is important not only in itself, but also in response to the dynamics of market change. Given the confusion among Romanians between the ecological and natural levels [58], more information and education of the consumer in this regard are essential.

Consumer access to relevant information plays a significant role in creating perceptions about the health and environmental benefits of organic fruits and vegetables, which implies that information is a driving force for any cognitive change that ultimately increases consumers' interest in consuming such fruits and vegetables. In this regard, governmental and non-governmental agencies are stepping up their efforts to disseminate information on organic farming in general and organic vegetables in particular through the internet, television, and newspapers [66].

Information and education campaigns could be developed using basic psychological needs and personal goals that can create or influence consumer motivations, such as the need for health, but also to preserve the ecological environment [29]. Another direction would be to educate customers about different organic certifications and certification bodies in order to create confidence in the minds of consumers about the authenticity of organic labels. This could be especially useful for consumers who buy mainly from agri-food markets, where food safety and contamination can affect product quality and consumer health. 
Maniatis [26] states that in this ongoing effort to inform consumers about organic products, additional attention must be paid to the specific definition of the product, in order to eliminate the confusion between the traditional, natural, and ecological levels.

The study contributes to a better knowledge of consumers' attitudes and perceptions towards organic fruits and vegetables in the case of Romania. Moreover, it provides a synthesis of the existing literature, as it is based on the results of various previous studies.

\subsection{Limitations and Future Research}

An important limitation of this research is represented by the small size of the sample used. It does not present statistical representativeness, neither in terms of its size nor in terms of the sociodemographic structure of the respondents that compose it. Thus, in our sample, women predominated, although at the level of the Romanian population the structure, according to the National Institute of Statistics (2019) [67], was 51.1\% women and $48.9 \%$ men. A similar difference can be observed in terms of residence. In our sample, over $79 \%$ of the population comes from urban areas, but in Romania, the population is divided $53.8 \%$ in urban areas and $46.2 \%$ in rural areas. In addition, the sampling method used was the convenience sample method.

Among the limitations of the research is the fact that the model did not take into account several implications or reactions that individuals could manifest at the behavioral level. The attitude of individuals could be studied in relation to other variables, not only with the intention of buying this category of products. In this sense, future research directions could be directed towards the analysis of new variables and correlations between them. In addition, using a larger sample, the multi-group moderating effect could be analyzed, taking into account a number of sociodemographic variables and studying their effect on the relationships within the model.

Author Contributions: Conceptualization, V.R.; format analysis, D.G.; methodology, V.R.; supervision, I.C.; validation, I.C.; visualization, A.F.C.; writing—original draft, V.R.; writing—review and editing, D.G. and A.F.C. All authors have read and agreed to the published version of the manuscript.

Funding: This research received no external funding.

Institutional Review Board Statement: Not applicable.

Informed Consent Statement: Not applicable.

Data Availability Statement: The data presented in this study are available on request from the corresponding author. The data are not publicly available due to privacy.

Conflicts of Interest: The authors declare no conflict of interest.

\section{References}

1. Grandval, F. Agroécologie: Où en Est-On? Inter-Réseaux Développement Rural: Nogent-sur-Marne, France, 2011; pp. 1-7.

2. Goldbach, D. Potentialul Agriculturii Biologice din Romania din Perspectiva Paradigmei s.c.p. In Conditiile Dezvoltarii Durabile; Pro Universitaria Publishing House: Bucuresti, Romania, 2014.

3. Sanders, J. (Ed.) Evaluation of the EU Legislation on Organic Farming; Thünen Institute of Farm Economics: Braunschweig, Germany, 2014.

4. Bryła, P. The development of organic food market as an element of sustainable development concept implementation. Probl. Ekorozw. 2015, 10, 79-88.

5. Bryla, P. Organic food online shopping in Poland. Br. Food J. 2018, 120, 1015-1027. [CrossRef]

6. Pawlewicz, A. Change of Price Premiums Trend for Organic Food Products: The Example of the Polish Egg Market. Agriculture 2020, 10, 35. [CrossRef]

7. Vindigni, G.; Janssen, M.A.; Jager, W. Organic food consumption: A multitheoretical framework of consumer decision making. $B r$. Food J. 2002, 104, 624-642. [CrossRef]

8. Davidovici, D.; Gavrilescu, D. Economia Creşterii Agroalimentare; Editura Editura Expert: Bucureşti, Romania, 2010.

9. Istudor, N.; Pelau, C. Consumer Behavior on the Fruits and Vegetables Market. Ann. Fac. Econ. Univ. Oradea Fac. Econ. 2011, 1,749-754.

10. Organic Framing in EU-European Commission. 2019. Available online: https://ec.europa.eu/info/sites/info/files/foodfarming-fisheries/farming/documents/market-brief-organic-farming-in-the-eu_mar2019_en.pdf (accessed on 17 January 2021). 
11. Peter, J.P.; Olson, J.C. Consumer Behavior and Marketing Strategy; McGraw-Hill/Irwin: Boston, MA, USA, 2008.

12. Torjusen, H.; Sangstad, L.; O’Doherty-Jensen, K.; Kjærnes, U. European Consumers' Conceptions of Organic Food: A Review of Available Research; National Institute for Consumer Research: Oslo, Norway, 2004.

13. Yiridoe, E.K.; Bonti-Ankomah, S.; Martin, R.C. Comparison of consumer's perception towards organic versus conventionally produced foods: A review and update of the literature. Renew. Agric. Food Syst. 2005, 20, 193-205. [CrossRef]

14. Radman, M. Consumer consumption and perception of organic products in Croatia. Br. Food J. 2005, 107, 263-273. [CrossRef]

15. Wier, M.; Hansen, L.G.; Andersen, L.M.; Millock, K. Consumer preferences for organic foods. In Organic Agriculture: Sustainability, Markets and Policies; CABI Publishing: Wallingford, UK, 2003; pp. 257-271.

16. Goyal, A.; Singh, N.P. Consumer perception about fast food. India: An exploratory study. Br. Food J. 2007, 109, 182-195. [CrossRef]

17. Kuhar, A.; Juvancic, L. Determinants of purchasing behaviour for organic and integrated fruits and vegetables in Slovenia. Agric. Econ. Rev. 2010, 11, 70-83.

18. Zanoli, R. (Ed.) The European consumer and organic food. In Organic Marketing Initiatives and Rural Development Series; University of Wales: Wales, UK, 2004; Volume 4.

19. Zhen, J.S.; Mansori, S. Young Female Motivations for Purchase of Organic Food in Malaysia. Int. J. Contemp. Bus. Stud. 2012, 3, 61-72.

20. Latacz-Lohmann, U.; Foster, C. From Niche to mainstream strategies for the marketing of organic food in Germany and the UK. Br. Food J. 1997, 99, 275-282. [CrossRef]

21. Groele, B.; Głąbska, D.; Gutkowska, K.; Guzek, D. Mother-Related Determinants of Children At-Home Fruit and Vegetable Dietary Patterns in a Polish National Sample. Sustainability 2019, 11, 3398. [CrossRef]

22. Wier, M.; Calverley, C. Market potential for organic foods in Europe. Br. Food J. 2002, 104, 45-62. [CrossRef]

23. Goksel, A.M.; Aykin, S.M.; Cengiz, S.; Ozkan, B. The role of demographic variables in purchasing decisions on fresh fruit and vegetables. J. Food Agric. Environ. 2009, 7, 106-110.

24. Brown, C. Consumers' preferences for locally produced food: A study in southeast Missouri. Am. J. Altern. Agric. 2003, 18, 213-224. [CrossRef]

25. Achilleas, K.; Anastasios, S. Marketing aspects of quality assurance systems: The organic food sector case. Br. Food J. 2008, 110, 829-839. [CrossRef]

26. Maniatis, P. Investigating factors influencing consumer decision-making while choosing green products. J. Clean. Prod. 2016, 132, 215-228. [CrossRef]

27. Tandon, A.; Dhir, A.; Kaur, P.; Kushwah, S.; Salo, J. Behavioral reasoning perspectives on organic food purchase. Appetite 2020, 154, 104786. [CrossRef]

28. Kihlberg, I.; Risvik, E. Consumers of Organic Foods-Value Segments and Liking of Bread. Food Qual. Prefer. 2007, 18, 471-481. [CrossRef]

29. Tandon, A.; Dhir, A.; Kaur, P.; Kushwah, S.; Salo, J. Why do people buy organic food? The moderating role of environmental concerns and trust. J. Retail. Cons. Serv. 2020, 57, 102247. [CrossRef]

30. Bean, M.; Sharp, J.S. Profiling alternative food system supporters: The personal and social basis of local and organic food support. Renew. Agric. Food Syst. 2011, 26, 243-254. [CrossRef]

31. Lund, T.B.; Andersen, L.M.; O'Doherty Jensen, K. The emergence of diverse organic consumers: Does a mature market undermine the search for alternative products? Sociol. Rural. 2013, 53, 454-478. [CrossRef]

32. Padel, S.; Foster, C. Exploring the gap between attitudes and behaviour: Understanding why consumers buy or do not buy organic food. Br. Food J. 2005, 107, 606-625. [CrossRef]

33. De-Magistris, T.; Gracia, A. Consumers' willingness-to-pay for sustainable food products: The case of organically and locally grown almonds in Spain. J. Clean. Prod. 2015, 118, 97-104. [CrossRef]

34. Hill, H.; Lynchehaun, F. Organic milk: Attitudes and consumption patterns. Br. Food J. 2002, 104, 526-542. [CrossRef]

35. Naspetti, S.; Zanoli, R. Organic Food Quality and Safety Perception throughout Europe Organic Food Quality and Safety Perception. J. Food Prod. Mark. 2009, 15, 249-266. [CrossRef]

36. Tandon, A.; Jabeen, F.; Talwar, S.; Sakashita, M.; Dhir, A. Facilitators and inhibitors of organic food buying behavior. Food Qual. Prefer. 2021, 88, 104077. [CrossRef]

37. Canavari, M.; Nocella, G.; Scarpa, R. Stated willingness-to pay for organic fruit and pesticide ban-an evaluation using both web-based and face-to face interviewing. J. Food Prod. Mark. 2005, 11, 107-134. [CrossRef]

38. Batte, M.T.; Hooker, N.H.; Haab, T.C.; Beaverson, J. Putting their money where their mouths are: Consumer willingness to pay for multi-ingredient, processed organic food products. Food Policy 2007, 32, 145-159. [CrossRef]

39. Marian, L.; Chrysochou, P.; Krystallis, A.; Thøgersen, J. The role of price as a product attribute in the organic food context: An exploration based on actual purchase data. Food Qual. Prefer. 2014, 37, 52-60. [CrossRef]

40. Feldmann, C.; Hamm, U. Consumers' perception and preferences for local food: A review. Food Qual. Prefer. 2015, 40, 152-164. [CrossRef]

41. Schleenbecker, R.; Hamm, U. Consumers' perception of organic product characteristics. A review. Appetite 2013, 71, 420-429. [CrossRef] [PubMed]

42. Giannakas, K. Information Asymmetries and Consumption Decisions in Organic Food Product Markets. Can. J. Agric. Econ. 2002, 50, 35-50. [CrossRef] 
43. Bostan, I.; Onofrei, M.; Gavriluță (Vatamanu), A.F.; Toderașcu, C.; Lazăr, C.M. An Integrated Approach to Current Trends in Organic Food in the EU. Foods 2019, 8, 144. [CrossRef] [PubMed]

44. Cetină, I.; Goldbach, D.; Manea, N.; Popescu, L. Marketing Strategies for Romanian Traditional Products. Econ. Eng. Agric. Rural Dev. 2018, 18, 93-100.

45. Halberg, N.; Alroe, H.; Knudsen, M.T.; Kristensen, E.S. (Eds.) Global Development of Organic Agriculture: Challenges and Promises; CABI Publishing: Wallingford, UK, 2006.

46. Hamm, U.; Gronefeld, F.; Halpin, D. Analysis of the European Market for Organic Food-Organic Marketing Initiatives and Rural Development (OMIaRD); University of Wales: Wales, UK, 2002; Volume 1.

47. Willer, H.; Yussefi, M.; Sorensen, N. (Eds.) The World of Organic Agriculture-Statistics and Emerging Trends; IFOAM: Bonn, Germany, 2008.

48. Reddy, G.P.; Murthy, M.R.K.; Meena, P.C. Value Chains and Retailing of Fresh Vegetables and Fruits, Andhra Pradesh. Agric. Econ. Res. Rev. 2010, 23, 455-460.

49. Chen, K.; Shepherd, A.W.; Silva, C.D. Changes in food retailing in Asia: Implications of supermarket procurement practices for farmers and traditional marketing systems. In Agricultural Management, Marketing and Finance Occasional; Paper No. 8; Food and Agriculture Organisation: Rome, Italy, 2005.

50. Stefanic, I.; Stefanic, E.; Haas, R. What the consumer really wants: Organic food market in Croatia. Die Bodenkult. 2001, $52,323-328$.

51. Squires, L.; Juric, B.; Cornwell, B.T. Level of market development and intensity of organic food consumption: Cross-cultural study of Danish and New Zealand consumers. J. Consum. Mark. 2001, 18, 392-409. [CrossRef]

52. Sobocińska, M.; Mazurek-Łopacińska, K.; Skowron, S.; Graczyk, A.; Kociszewski, K. The Role of Marketing in Shaping the Development of the Market of Organic Farming Products in Poland. Sustainability 2021, 13, 130. [CrossRef]

53. EUROSTAT. Agriculture, Forestry and Fishery Statistics; European Union: Brussels, Belgium, 2019. Available online: https:/ /ec. europa.eu/eurostat/documents/3217494/10317767/KS-FK-19-001-EN-N.pdf/742d3fd2-961e68c1-47d0-11cf30b11489 (accessed on 5 February 2021).

54. Research Insitute of Organic Agriculture FiBL. Organic Agriculture Worldwide: Key Results from the FiBL Survey on Organic Agriculture Worldwide. 2019. Available online: https://www.organic-world.net/fileadmin/documents/yearbook/2019/FiBL2019-Global-data-2017.pdf (accessed on 14 February 2021).

55. Codreanu, C. Conceptul de agricultură ecologică-bază importantă pentru dezvoltarea agriculturii durabile în România. Rev. Lucrari Ştiinţifice Seria Agron. 2007, 50, 298-302.

56. Freeze, R.D.; Raschke, R.L. An Assessment of Formative and Reflective Constructs in IS Research. In Proceedings of the Fifteenth European Conference on Information Systems, ECIS, St. Gallen, Switzerland, 1 January 2007.

57. Ministerul Agriculturii si Dezvoltarii Durabile (MADR), Agricultura Ecologică. Available online: https://www.madr.ro/ agricultura-ecologica.html (accessed on 10 May 2021).

58. Stancu, A. Consumatorii dau Propria Definitie Categoriei Bio. Rev. Progresiv. 2014. Available online: https://revistaprogresiv.ro/ articles/consumatorii-dau-propria-definitie-categoriei-bio (accessed on 10 May 2021).

59. European Commission. Available online: https:/ / ec.europa.eu/info/food-farming-fisheries/farming/organic-farming/organicproduction-and-products_en (accessed on 5 June 2021).

60. Chrysargyris, A.; Xylia, P.; Kontos, Y.; Ntoulaptsi, M.; Tzortzakis, N. Consumer behavior and knowledge on organic vegetables in Cyprus. Food Res. 2017, 1, 57-65. [CrossRef]

61. Talwar, S.; Jabeen, F.; Tandon, A.; Sakashita, M.; Dhir, A. What drives willingness to purchase and stated buying behavior toward organic food? A Stimulus-Organism-Behavior-Consequence (SOBC) perspective. J. Clean. Prod. 2021, 293, 125882. [CrossRef]

62. Lee, H.J.; Yun, Z.S. Consumers' perceptions of organic food attributes and cognitive and affective attitudes as determinants of their purchase intentions toward organic food. Food Qual. Prefer. 2015, 39, 259-267. [CrossRef]

63. Financial Intelligence, Analiză-Vânzările de Produse Alimentare Ecologice au Atins 65 Milioane USD. 2020. Available online: https:/ / financialintelligence.ro/analiza-vanzarile-de-produse-alimentare-ecologice-au-atins-65-milioane-usd/ (accessed on 30 July 2021).

64. Kongsom, W.; Kongsom, C. Consumer Behavior and Knowledge on Organic Products in Thailand. World Acad. Sci. Eng. Technol. Int. J. Econ. Manag. Eng. 2016, 10, 2534-2538.

65. World Vision Romania, Studiul Romanii si Agricultura. 2019. Available online: https://worldvision.ro/wp-content/uploads/20 20/05/Romanii-si-agricultura.pdf (accessed on 20 May 2021).

66. Delcea, C.; Cotfas, L.-A.; Trică, C.L.; Crăciun, L.; Molanescu, A.G. Modeling the Consumers Opinion Influence in Online Social Media in the Case of Eco-friendly Products. Sustainability 2019, 11, 1796. [CrossRef]

67. Institutul National de Statistica, Romania in Cifre. 2019. Available online: https://insse.ro/cms/sites/default/files/field/ publicatii/romania_in_cifre_2019_2.pdf (accessed on 25 May 2021). 